\title{
Value Co-Creation pada Bisnis Syariah Konstruksi Oil dan Gas di Indonesia
}

\author{
Sukma Nugraha \\ Universitas Garut \\ Fakultas Kewirausahaan, Jalan Jati 42B Tarogong Kaler \\ sukma@uniga.ac.id
}

\begin{abstract}
Progress in terms of technology and information now has given rise to new trends in the economic field. In supporting a company's business performance, the term value co-creation creation is known. The research method used is descriptive survey and explanatory survey methods with organizational analysis units. The results of this study are the development of other variables that affect customer trust and repurchase intention and questioners will be distributed to related industries that have the same population as PT. Mutiara Global Industry as a company in the field of oil and gas and steel construction.
\end{abstract}

\begin{abstract}
Abstrak- Kemajuan segi teknologi dan informasi saat ini telah melahirkan kecenderungan baru dalam bidang ekonomi. Dalam mendukung kinerja bisnis suatu perusahaan, dikenal istilah value co-creation creation. Metode penelitian yang digunakan adalah metode descriptive survey dan explanatory survey dengan unit analisis organisasi. Hasil dari penelitian ini adalah adanya pengembangan terhadap variable -variable lainnya yang mempengaruhi terhadap kepercayaan customer dan repurchase intention dan questioner akan di sebar ke industry terkait yang memiliki populasi yang sama dengan PT. Mutiara Global Industry sebagai perusahaan di bidang oil and gas dan konstruksi baja.
\end{abstract}

Kata Kunci- Value Co-Creation

\section{PENDAHULUAN}

Value co-creation berawal dari prinsip-prinsip ekonomi makro yang dapat digunakkan sebagai ukuran kinerja dan untuk penciptaan kekayaan ekonomi pada sektor ekonomi atau industri [1]. Tujuan untuk menambah nilai pada umumnya adalah motivasi utama pada kegiatan ekonomi, maka terdapat pemahaman mengenai konsep value co-creation yaitu bahwa value co-creation berasal dari entitas ekonomi yang mewakili penciptaan kekayaan dan berkontribusi terhadap produk domestik bruto. Hal ini diukur dengan sejauh mana nilai barang yang ditingkatkan antara titik waktu dimana barang diperoleh oleh perusahaan dan titik waktu dimana barang (sendiri atau dikombinasikan dengan barang lain) dijual atau tersedia untuk dijual oleh perusahaan [2]. Salah satu tujuan dari value co-creation adalah menciptakan kemampuan intelektual. Intellectual capital (IC) adalah kajian penelitian baru yang mendapatkan perhatian cukup besar dari para ahli di berbagai disiplin seiring dengan pertumbuhan ekonomi yang berbasis pada pengetahuan (knowledge-based economy) [3]. Dari sisi akuntansi, sejumlah penelitian telah dilakukan di berbagai negara untuk mengkaji bagaimana metode untuk mengidentifikasi, mengukur, melaporkan dan menyajikannya dalam laporan perusahaan [4].

PT.Mutiara Global Industry (PT MGI) merupakan sebuah perusahaan yang bergerak di bidang konstruksi baja. Berdiri sejak tahun 2011 dengan produk spesifik di bidang konstruksi Steel untuk Offshore Minyak dan Gas. Visi PT MGI adalah 'Menjadi perusahaan konstruksi terbaik nasional dengan pemberdayaan sumber daya manusia yang professional, bermartabat luhur dan mengedepankan tauhid'. Jumlah karyawan yang dimiliki sebanyak 150 orang dengan berbagai keterampilan. Sejak tahun 2017 harga minyak dunia menurun, sehingga menjadi tantangan utama bagi PT MGI untuk meningkatkan laba dan memanfaatkan sumber dayanya dengan lebih baik selama penjualan menurun sejalan dengan penurunan harga minyak di dunia. Evaluasi terhadap kekuatan dan kelemahan internal perusahaan serta peluang dan ancaman eksternal menjadi landasan bagi analisis strategis dan rencana pemasaran . Rencana tersebut berfokus pada strategi pertumbuhan perusahaan, menyarankan caracara di mana ia dapat membangun hubungan pelanggan yang sudah ada, dan pada pengembangan produk dan / atau layanan baru yang ditargetkan untuk pelanggan tertentu. Sejak berjalan PT MGI memasarkan produk yang di gunakan untuk perlengakapan pengeboran minyak atau gas dan saat ini menggunakan strategy pemasararan Bisnis-toBisnis (B to B) [5]. Didirikan sebagai perusahaan konstruksi , PT MGI telah berkembang menjadi fabricator konstruksi baja untuk alat alat pengeboran lepas pantai dan gas yang dibuat khusus dan memiliki spesifikasi yang tinggi. Sejak berdiri tahun 2011 perkembangan penjualan meningkat dari tahun ke tahun dengan sejalan meningkatnya harga minyak 
dunia tahun 2016 mencapai 100USD/Barrel. Tetapi di tahun 2017 perubahan harga minyak dunia sangat signifikan berubah menurun drastis hingga 50/Barrel di tahun 2019 , hal ini mengakibatkan jumlah pengeboran lepas pantai dan daratan di seluruh dunia menurun atau menunda setiap perusahaan untuk melakukan pengeboran minyak.

\section{KAJIAN PUSTAKA}

\section{Kekuatan Kompetitif}

Persaingan PT MGI dalam industri konstruksi sangat kuat pada basis lokal. Angka penjualan untuk industri secara keseluruhan sulit diperoleh karena sangat sedikit bisnis yang dilakukan dalam skala nasional yang focus di konstruksi offshore. Persaingan yang ketat untuk mendapatkan pekerjaan konstruksi sangat tinggi karena penurunan jumlah pengeboran dan perusahaan harus tetap berjalan. Hal yang paling besar di hadapi adalah banyaknya perang harga antara kontraktor untuk mendapatkan pekerjaan [6]. Selain harga hal lainnya adalah banyak memberikan service tambahan kepada operator pengeboran (contoh Chevron, Premiere Oil, Conoco Philips) agar produk dapat di pakai. Seiring dengan penurunan harga minyak dunia, operator pengeboran banyak yang tidak mampu untuk bersaing pula dalam pengeboran, tidak sedikit operator pengeboran yang gulung tikar atau melakukan merger seperti Baker Hughes.

\section{Kekuatan Ekonomi}

Secara nasional, tingkat pertumbuhan ekonomi di Indonesia pada 2018 meningkat. Badan Pusat Statistik (BPS) merilis data perekonomian Indonesia tahun 2018 tumbuh 5,17 persen, lebih tinggi dibanding capaian tahun 2017 sebesar 5,07 persen. termasuk di sector infrastruktur. Adapun, pertumbuhan sektor konstruksi tercatat naik tipis menjadi 5,79\% pada kuartal III/2018 dibandingkan dengan posisi kuartal II/2018 sebesar 5,73\%. Kendati tumbuh tipis, struktur konstruksi dalam PDB mengalami peningkatan yang cukup signifikan. Pada kuartal III/2018, porsi konstruksi dalam perekonomian Indonesia mencapai $10,36 \%$. Angka ini meningkat dibandingkan dengan posisi empat tahun lalu di mana kontribusi sektor konstruksi masih di kisaran $9 \%$. Berdasarkan laporan perusahaan riset dan konsultan, BCI Asia, nilai pasar kontruksi Indonesia tahun ini diestimsai mencapai Rp451,3 triliun atau tumbuh 3\% dibandingkan dengan tahun lalu. Sebanyak $65 \%$ dari ceruk pasar ini disumbang konstruksi pekerjaan sipil dan sisanya konstruksi bangunan. Untuk diketahui, segmen pekerjaan sipil mencakup infrastruktur, transportasi, dan utilitas. Nilai kontrak konstruksi segmen ini diperkirakan tumbuh $4 \%$ pada 2018 menjadi Rp293,82 triliun.

3. Kekuatan politik

Dalam lima tahun masa pemerintahan Joko Widodo-Jusuf Kalla (2014-2019), pembangunan infrastruktur merupakan salah satu program yang gencar dilaksanakan. Pembangunan infrastruktur dianggap akan meningkatkan konektivitas dan merangsang daya saing antardaerah di seluruh Indonesia. Infrakstruktur dibangun meliputi jalan dan jembatan, kereta api, perbaikan bandara, pelabuhan. Indonesia secara politik melakukan pemilihan presiden serta pemimpin legislative di bulan April 2019. Dalam masa jabatan keduanya, Presiden terpilih Jokowi mengatakan akan membangun infrastruktur lebih cepat pada 5 tahun mendatang. Hal tersebut disampaikan Jokowi dalam acara syukuran bersama relawan dan partai koalisi pendukungnya dengan tema "Visi Indonesia" di Sentul International Convention Center (SICC), Bogor, Jawa Barat, pada Minggu (14/7). Infrastruktur-infrastruktur akan dibangun di kawasan ekonomi kecil dan kawasan ekonomi khusus, kawasan persawahan, kawasan perkebunan, dan tambak-tambak perikanan [7].

4. Kekuatan Hukum dan Peraturan

Pada tahun 2017 pemerintah mengesahkan UU no 2 tahun 2017 tentang jasa konstruksi, dimana pada pada bagian keempat pasal 32-35 UU ini pemerintah membuka peluang bagi Badan usaha jasa konstruksi asing dan usaha perseorangan jasa konstruksi asing. Hal ini menjadi tantangan bagi PT MGI untuk dapat bersaing dengan perusahaan asing (Cina) yang telah diketahui memiliki sumber daya yang terampil dan efisien. Selain itu mengacu pada UU Nomor 2/2017 tersebut Jasa Konstruksi, pengguna dan penyedia jasa wajib tenaga kerja bersertifikat. Saat ini sertifikasi tenaga kerja konstruksi masih sangat rendah yakni di bawah $10 \%$ atau hanya 720.000 dari 8,10 juta tenaga kerja konstruksi.

5. Kekuatan Teknologi.

Tahun 2018 merupakan tahun yang cukup menarik di bidang industri konstruksi dunia. Hal ini terjadi lantaran adanya perubahan terhadap rantai pasokan material dan perubahan pada penerapan teknologinya. Adanya berbagai tren terbaru di dunia industri konstrusksi membuat perusahaan-perusahaan tetap kompetitif dan dapat mempersiapkan diri menghadapi pesatnya perkembangan industri konstruksi di masa depan [8].

a. Makin Majunya Teknologi dan Integrasi

Hadirnya berbagai macam teknologi terbaru seperti perangkat lunak membuat industri konstruksi 
berkembang menjadi lebih baik dan lebih maju. Untuk mengatur proyek konstruksi dapat dilakukan dengan menggunakan perangkat lunak, mulai dari penjadwalan, pengerjaan, sampai penyelesaian proyek konstruksi. Di sisi lain, kemajuan teknologi dalam industri konstruksi tak hanya sebatas pada perangkat lunak saja, tetapi juga penggunaan Drone. Drone merupakan salah satu alat yang populer karena alat ini dapat dioperasikan oleh perusahaan konstruksi dengan biaya yang lebih murah. Drone dan foto udara berfungsi untuk menangkap foto dan video secara lanskap. Hasilnya dapat meningkatkan pengawasan keamanan dan keselamatan di sekitar proyek.Selain itu, adanya drone dapat menambah lebih banyak informasi sebagai hasil dari data survei. Kedua perangkat tersebut tentu akan sangat membantu untuk menghasilakn kualitas proyek yang lebih baik lagi [9]. b. Peningkatan Konstruksi Modular dan Prefabrikasi

$$
\text { Peningkatan konstruksi modular dan }
$$
prefabrikasi merupakan bagian dari tren industri konstruksi dunia yang akan terus menjadi tren hingga 2019. Beberapa perusahaan konstruksi modular membuat sebuah berita di mana mereka dapat membuat bangunan perumahan dan juga komersial. Konstruksi modular adalah pendekatan prefabrikasi guna membangun struktur berulang. Sebagai contoh yaitu gedung perkantoran, hotel, dan apartemen yang cocok menggunakan bangunan modular dan prefabrikasi. Dikarenakan jumlah penggunaan material, waktu, dan fleksibilitasnya, tren konstruksi prefabrikasi dan modular semakin meningkat. Penggunaan konstruksi modular dan prefabrikasi mampu menghemat lebih banyak waktu dan anggaran perusahaan. Material dari konstruksi modular dibangun di dalam pabrik, jadi perusahaan tidak perlu khawatir terkait masalah cuaca. Material tersebut juga dapat didaur ulang, sehingga tren kosntruksi ini dapat menghindari penggunaan material yang berlebihan. Tent hal tersebut cukup membantu dalam mengurangi limbah sebagai efek samping dari suatu proyek. Selain itu, material dari proyek yang dibangun bisa memenuhi spesifikasi yang diinginkan secara cepat dan mudah . c. Penurunan Jumlah Tenaga Kerja

Saat ini terdapat hampir 250.000 lowongan pekerjaan di industri konstruksi di Amerika Serikat. Akan tetapi, angka tersebut diperkirakan tidak akan membaik dalam waktu dekat ini. Masalah utama tren ini adalah pengerjaan proyek yang cenderung melambat atau bahkan terhenti dan menyebabkan berkurangnya tenaga kerja. Hal itu merupakan salah satu faktor yang membuat perusahaan beralih dari tren konstruksi ini ke konstruksi modular dan prefabrikasi guna mengejar target terkait waktu pengerjaan proyek tanpa mengurangi tenaga kerjanya.

\section{d. Konstruksi Berteknologi Ramah Lingkungan}

Tren konstruksi berteknologi ramah lingkungan sekarang sedang menjadi tren industri konstruksi dunia. Sehingga semakin banyak perencanaan dan juga pengerjaan suatu proyek dengan menggunakan tren konstruksi tersebut. Prinsip dari teknik konstruksi ini yaitu membangun suatu proyek dengan tetap bertanggung jawab atas lingungan dan penggunaan sumber daya alam. Dalam praktiknya, dimulai dari perencanaan dan desain, kemudian konstruksi di lapangan, pemeliharaan, dan juga pembongkaran. Metode seperti ini tidak jauh berbeda dengan metode bangunan konvensional, karena tetap mempertimbangkankan utilitas, daya tahan, dan nilai ekonomis. Hal-hal tersebut adalah bagian pentng dari proses konstruksi. Untuk mewujudkan visi yang telah ditetapkan, PT MGI dituntut untuk menyesuaikan dengan semua perubahan yang ada dengan target yang ingin dicapai adalah menghasilkan kualitas produk yang maksimal dengan cost yang efisien [10].

6. Kekuatan sosiokultural.

Sosiokultural berpengaruh pada kelancaran dalam dunia bisnis termasuk bidang konstruksi. Beberapa fungsi bisnis dipengaruhi oleh sosiokultural adalah di pemasaran, menajemen sumber daya manusia, produksi dan keuangan. Bisnis konstruksi masih didominasi oleh perusahaan-perusahaan besar (sebagian besar perusahaan asing) yang memiliki karakter sosiokultural yang berbeda. Dalam menjalankan fungsi bisnis nya PT MGI menyesuaikan dengan sosiokultural perusahaan tersebut. Contoh British petroleum (BP) sebagai operator pengeboran akan memberikan pekerjaan turunannya kepada perusahaan Australia sebagai perusahaan sebangsa yaitu PT Leighton Contractor Indonesia atau Mc Connel Dowell. PT MGI memfokuskan pengembangan sumber daya manusia yang diarahkan pada konsep nilai kejujuran, loyalitas, kebersamaan, kekeluargaan dan transparansi. Dimana dari keseluruhan nilai nilai tersebut bersumber pada keimanan seseorang (Tauhid) .

\section{METODE PENELITIAN}

Metode penelitian yang digunakan adalah metode descriptive survey dan explanatory survey dengan unit analisis organisasi, yaitu Perusahaan Konstruksi berbasis Syariah dan unit observasi adalah pengelola perusahaan di Jawa Barat yang terdiri atas Manager atau Owner. Metode descriptive survey merupakan metode penelitian yang bertujuan untuk 
memperoleh deskripsi dari obyek yang diteliti, sedangkan metode explanatory survey merupakan metode penelitian yang bertujuan untuk mengetahui karakteristik variabel dengan meneliti sejumlah sampel. Data dikumpulkan dalam rentang waktu "one shoot"- cross sectional, yaitu dilakukan dengan data yang hanya sekali dikumpulkan dalam rangka menjawab pertanyaan penelitian.

\section{HASIL DAN PEMBAHASAN}

1. Evaluasi Outer Model (Evaluasi Model

\section{Pengukuran)}

Evaluasi terhadap model pengukuran indikator meliputi pemerikasaan individual item reliability, internal consistency, atau construct reliability, average variance extracted, dan discriminant validity. Ketiga pengukuran pertama dikelompokan dalam convergent validity.

\subsection{Convergent Validity}

Convergent validity terdiri dari tiga pengujian yaitu reliability item (validitas tiap indikator), composite reability, dan average variance extracted (AVE). Convergent validity digunakan untuk mengukur seberapa besar indikator yang ada dapat menerangkan dimensi. Artinya semakin besar convergent validity maka semakin besar kemampuan indikator tersebut dalam menerapkan dimensinya.

\subsection{Composite Reliability}

Statistik yang digunakan dalam composite reliability atau reabilitas konstrak adalah cronbach's alpha dan D.G rho (PCA). Nilai cronbach's alpha dan D.G rho (PCA) di atas 7,0 menunjukan konstrak memiliki reabilitas atau keterandalan yang tinggi sebagai alat ukur. Nilai batas 0,7 keatas berarti dapat diterima dan di atas 0,8 dan 0,9 berarti sangat memuaskan (Nunnally dan Bernstein, 1994 dalam Sofyan Yamin dan Heri Kurniawan, 2011:19). Berikut adalah nilai composite reliability pada Tabel 1.

TABEL 1. COMPOSITE RELIABILITY

\begin{tabular}{|c|c|c|c|}
\hline Latent variable & $\begin{array}{c}\text { Dimension } \\
s \\
\end{array}$ & $\begin{array}{c}\text { Cronbach' } \\
\text { s alpha }\end{array}$ & $\begin{array}{l}\begin{array}{l}\text { D.G. rho } \\
\text { (PCA) }\end{array} \\
\end{array}$ \\
\hline Customer Trust & 5 & 0,937 & 0,938 \\
\hline $\begin{array}{l}\text { Quality Product } \\
\text { and Service }\end{array}$ & 5 & 0,915 & 0,924 \\
\hline Religiosity & 5 & 0,886 & 0,903 \\
\hline $\begin{array}{l}\text { Repurchase } \\
\text { Intention }\end{array}$ & 5 & 0,916 & 0,922 \\
\hline $\begin{array}{l}\text { Value Co- } \\
\text { Creation }\end{array}$ & 5 & 0,831 & 0,857 \\
\hline
\end{tabular}

Sumber : Hasil Pengolahan Data, 2019

Berdasarkan Tabel 1 menunjukan bahwa nilai cronbach's alpha dan D.G rho (PCA) untuk variabel
Customer Trust sebesar 0,937 dan 0,938 sehingga dikatakan sangat memuaskan. Begitu pula pada variabel Quality Product and Service memiliki nilai cronbach's alpha sebesar 0,915 dan D.G rho (PCA) sebesar 0,924 sehingga dikatakan sangat memuaskan. Sementara variabel religiosity memiliki nilai cronbach's alpha sebesar 0,886 dan memiliki nilai cronbach's alpha sebesar 0,903 sehingga dikatakan sangat memuaskan. Variabel Repurchase Intention memiliki nilai cronbach's alpha sebesar 0,916 dan D.G rho (PCA) sebesar $\quad 0,922$ sehingga dikatakan sangat memuaskan. Sedangkan variabel Value CoCreation memiliki nilai cronbach's alpha sebesar 0,831 dan D.G rho (PCA) sebesar 0,857 sehingga dapat dikatakan tingkat reliabilitasnya baik.

\subsection{Convergent Validity \\ Average Variance Extracted}

(AVE) menggambarkan besaran variance yang mampu dijelaskan oleh item-item dibandingkan dengan varian yang disebabkan oleh error pengukuran. Standarnya adalah bila nilai AVE di atas 0,5 maka dapat dikatakan bahwa konstrak memiliki convergent validity yang baik. Artinya variabel laten dapat menjelaskan ratarata lebih dari setengah variance dari indikatorindikatornya. Berikut adalah hasil convergent validity yang dijelaskan melalui Average Variance Extracted (AVE) pada Tabel 4.16

TABEL 2. CONVERGENT VALIDITY

\begin{tabular}{lc}
\hline \multicolumn{1}{c}{ Latent Variable } & $\begin{array}{c}\text { Mean Communalities } \\
\text { (AVE) }\end{array}$ \\
\hline Customer Trust & 0,799 \\
Quality Product and & 0,750 \\
Service & 0,687 \\
Religiosity & 0,750 \\
Repurchase Intention & 0,592 \\
Value Co-Creation & \\
\hline
\end{tabular}

Sumber : Hasil Pengolahan Data, 2019

Berdasarkan Tabel 2 menunjukan bahwa nilai AVE Customer Trust sebesar 0,799, Quality Product and Service sebesar 0,750, Religiosity sebesar 0,687, Repurchase Intention sebesar 0,750, dan Value CoCreation sebesar 0,592. Nilai kelima variabel berada di atas 0,5 sehingga konstrak memiliki convergent validity yang baik dimana variabel laten dapat menjelaskan rata-rata lebih dari setengah variance dari indikator-indikatornya.

\section{$1.4 \quad$ Discriminant Validity}

Pemeriksaan discriminant validity dari model pengukuran reflektif yang dinilai berdasarkan cross loading dan membandingkan antara nilai AVE dengan kuadran korelasi antarkonstrak. Ukuran cross loading adalah adalah membandingkan korelasi indikator 
dengan konstraknya dan konstrak dari blok lain. Discriminant validity yang baik akan mampu menjelaskan variabel indikatornya lebih tinggi dibandingkan dengan menjelaskan varian dari indikator konstrak yang lain. Berikut adalah nilai discriminant validity untuk masing-masing indikator.

TABEL 3. DISCRIMINANT VALIDITY

\begin{tabular}{cccccc}
\hline & CT & QPS & R & RI & VCC \\
\hline CT & 0,894 & & & & \\
QPS & 0,834 & 0,866 & & & \\
R & 0,667 & 0,650 & 0,829 & & \\
RI & 0,896 & 0,800 & 0,715 & 0,866 & \\
VCC & 0,815 & 0,822 & 0,625 & 0,782 & 0,770 \\
\hline
\end{tabular}

Sumber : Hasil Pengolahan Data, 2019

4.4 Evaluasi Inner Model (Model Struktural)

Ada beberapa tahap dalam mengevaluasi model structural. Pertama adalah melihat signifikansi hubungan antara konstrak. Hal ini dapat dilihat dari koefisien jalur (path coefficient) yang menggambarkan kekuatan hubungan antar konstrak.

\subsubsection{Path Coefficient}

Melihat signifikansi hubungan antara konstrak dapat dilihat dari koefisien jalur (path coefficient). Tanda dalam path coefficient harus sesuai dengan teori yang dihipotesiskan, untuk menilai signifikansi path coefficient dapat dilihat dari t test (critical ratio) yang diperoleh dari proses bootstrapping (resampling method).

\begin{tabular}{lc}
\multicolumn{2}{l}{ TABEL 4. PATH COEFFICIENT } \\
\hline & $\mathrm{R}^{2}$ \\
\hline Customer Trust & 0,151 \\
Quality Product and Service & 0,325 \\
Religiosity & 0,443 \\
Repurchase Intention & 0,453 \\
Value Co-Creation & 0,125 \\
\hline
\end{tabular}

Sumber : Hasil Pengolahan Data, 2019

Tabel di atas memerlihatkan bahwa nilai $\mathrm{R}^{2}$ untuk konstrak Customer Trust adalah sebesar 0,151. Artinya bahwa Customer Trust mampu menjelaskan varian Customer Trust sebesar $15,1 \%$. Nilai $\mathrm{R}^{2}$ untuk konstrak Quality Product and Service adalah sebesar 0,325, artinya bahwa Customer Trust mampu menjelaskan varian Quality Product and Service sebesar $32,5 \%$. Nilai $\mathrm{R}^{2}$ untuk konstrak Religiosity adalah sebesar 0,443, artinya bahwa Customer Trust dan Quality Product and Service mampu menjelaskan varian Religiosity sebesar 44,3\%. Nilai $\mathrm{R}^{2}$ untuk konstrak Repurchase Intention adalah sebesar 0,453, artinya bahwa Customer Trust dan Quality Product and Service mampu menjelaskan varian Repurchase
Intention sebesar 45,3\%. Nilai $\mathrm{R}^{2}$ untuk konstrak Value Co-Creation adalah sebesar 0,125.

TABEL 5. PENGUJIAN HIPOTESIS

\begin{tabular}{cccccc}
\hline & $\begin{array}{c}\text { Original } \\
\text { Sample (O) }\end{array}$ & $\begin{array}{c}\text { Sample } \\
\text { Mean } \\
(\mathbf{M})\end{array}$ & $\begin{array}{c}\text { Standard } \\
\text { Deviation } \\
\text { (STDEV) }\end{array}$ & $\begin{array}{c}\text { T Statistics } \\
(\text { (O/STERR) }\end{array}$ & PValues \\
\hline $\mathrm{CT} \rightarrow \mathrm{RI}$ & 0,896 & 0,901 & 0,032 & 28,330 & 0,000 \\
$\mathrm{QPS} \rightarrow \mathrm{CT}$ & 0,436 & 0,444 & 0,182 & 2,393 & 0,012 \\
$\mathrm{QPS} \rightarrow \mathrm{RI}$ & 0,390 & 0,400 & 0,162 & 2,416 & 0,011 \\
$\mathrm{R} \rightarrow \mathrm{CT}$ & 0,161 & 0,110 & 0,148 & 1,084 & 0,143 \\
$\mathrm{R} \rightarrow \mathrm{RI}$ & 0,144 & 0,101 & 0,136 & 1,057 & 0,149 \\
$\mathrm{VCC} \rightarrow$ & 0,357 & 0,396 & 0,148 & 2,409 & 0,011 \\
$\mathrm{CT}$ & 0,320 & 0,356 & 0,127 & 2,516 & 0,009 \\
VCC $\rightarrow$ RI & 0 & &
\end{tabular}

Hipotesis 1 :

Berdasarkan tabel di atas dapat dilihat bahwa hubungan antara VCC dengan CT adalah signifikan dengan nilai T-statistik sebesar 2,409 $(>1,96)$. Nilai original sample estimate adalah positif yaitu sebesar 0,357 yang menunjukkan bahwa arah hubungan antara VCC dengan CT adalah positif. Dengan demikian hipotesis $\mathrm{H}_{6}$ dalam penelitian ini yang menyatakan bahwa "Value Co-Creation (VCC) berpengaruh terhadap Customer Trust (CT)" diterima.

Hipotesis 2:

Berdasarkan tabel di atas dapat dilihat bahwa hubungan antara VCC dengan RI adalah signifikan dengan nilai T-statistik sebesar 2,516 $(>1,96)$. Nilai original sample estimate adalah positif yaitu sebesar 0,320 yang menunjukkan bahwa arah hubungan antara VCC dengan RI adalah positif. Dengan demikian hipotesis $\mathrm{H}_{7}$ dalam penelitian ini yang menyatakan bahwa "Value Co-Creation (VCC) berpengaruh terhadap Repurchase Intention (RI)" diterima.

Besarnya kontribusi variabel masing-maisng variabel dapat dilihat dari nilai koefesien jalurnya (path coefficient) sebagai berikut.

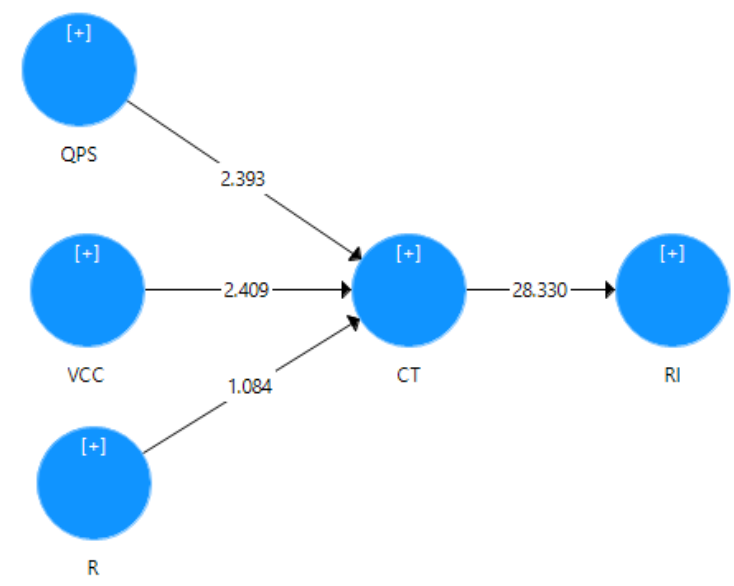

Gambar 1. Diagram Struktural 


\section{KESIMPULAN DAN SARAN}

Adanya pengembangan terhadap Variable Variable lainnya yang mempengaruhi terhadap kepercayaan customer dan repurchase intention dan questioner akan di sebar ke industry terkait yang memiliki populasi yang sama dengan PT.Mutiara Global Industry sebagai perusahaan di bidang Oil and Gas dan konstruksi Baja.

\section{REFERENSI}

[1] N. A. Hamdani, A. Solihat, and G. A. F. Maulani, "The Influence of Information Technology and Co-Creation on Handicraft SME Business Performance," Int. J. Recent Technol. Eng., vol. 8, no. 1S, pp. 151-154, 2019.

[2] A. Haller and C. van Staden, "The value added statement - an appropriate instrument for integrated reporting," Accounting, Audit. Account. J., vol. 27, no. 7, pp. 1190-1216, 2014.

[3] N. A. Hamdani, "Building knowledge-creation for making business competition atmosphere in SMEs of Batik," Manag. Sci. Lett., vol. 8, pp. 667-676, 2018.

[4] N. A. Hamdani and G. A. F. Maulani, "Analysis of Marketing of Sharia Banking Service
Products Based on Consumer Perception," no. January 2017, pp. 515-520, 2018.

[5] J. Marcos-Cuevas, S. Nätti, T. Palo, and J. Baumann, "Value co-creation practices and capabilities: Sustained purposeful engagement across B2B systems," Ind. Mark. Manag., vol. 56, pp. 97-107, 2016.

[6] S. Nugraha, "Kecerdasan Emosional dan Perilaku Kewarganegaraan Organisasi pada Pegawai Badan Kepegawaian Daerah," Bus. Innov. Entrep. J., vol. 1, no. 1, pp. 62-67, 2019.

[7] A. Supriyatna, E. Yulianto, N. A. Hamdani, and G. A. F. Maulani, "Budaya Perusahaan: Penerapan Good Corporare Governance Serta Implikasinya Terhadap," Bus. Innov. Entrep. J., vol. 1, no. 1, pp. 11-20, 2019.

[8] M. Kohtamäki and R. Rajala, "Theory and practice of value co-creation in B2B systems," Ind. Mark. Manag., vol. 56, pp. 4-13, 2016.

[9] E. Jaakkola and T. Hakanen, "Value cocreation in solution networks," Ind. Mark. Manag., vol. 42, no. 1, pp. 47-58, 2013.

[10] I. Assiouras, G. Skourtis, A. Giannopoulos, D. Buhalis, and M. Koniordos, "Value co-creation and customer citizenship behavior," Ann. Tour. Res., vol. 78, no. May, p. 102742, 2019. 